\title{
Epigenetic silencing of the 3p22 tumor suppressor DLEC1 by promoter CpG methylation in non-Hodgkin and Hodgkin lymphomas
}

Zhaohui Wang ${ }^{1,2+}$, Lili Li ${ }^{1,2+}$, Xianwei Su², Zifen Gao ${ }^{3}$, Gopesh Srivastava ${ }^{4}$, Paul G Murray ${ }^{5}$, Richard Ambinder ${ }^{6}$ and Qian Tao ${ }^{1,2,6^{*}}$

\begin{abstract}
Background: Inactivaion of tumor suppressor genes (TSGs) by promoter CpG methylation frequently occurs in tumorigenesis, even in the early stages, contributing to the initiation and progression of human cancers. Deleted in lung and esophageal cancer 1 (DLEC1), located at the 3p22-21.3 TSG cluster, has been identified frequently silenced by promoter CpG methylation in multiple carcinomas, however, no study has been performed for lymphomas yet.

Methods: We examined the expression of DLEC1 by semi-quantitative reverse transcription (RT)-PCR, and evaluated the promoter methylation of DLEC1 by methylation-specific PCR (MSP) and bisulfite genomic sequencing (BGS) in common lymphoma cell lines and tumors.

Results: Here we report that $D L E C 1$ is readily expressed in normal lymphoid tissues including lymph nodes and PBMCs, but reduced or silenced in 70\% (16/23) of non-Hodgkin and Hodgkin lymphoma cell lines, including 2/6 diffuse large B-cell (DLBCL), 1/2 peripheral T cell lymphomas, 5/5 Burkitt, 6/7 Hodgkin and 2/3 nasal killer (NK)/T-cell lymphoma cell lines. Promoter CpG methylation was frequently detected in 80\% (20/25) of lymphoma cell lines and correlated with DLEC1 downregulation/silencing. Pharmacologic demethylation reversed DLEC1 expression in lymphoma cell lines along with concomitant promoter demethylation. DLEC1 methylation was also frequently detected in 32 out of 58 (55\%) different types of lymphoma tissues, but not in normal lymph nodes. Furthermore, DLEC1 was specifically methylated in the sera of 3/13 (23\%) Hodgkin lymphoma patients.
\end{abstract}

Conclusions: Thus, methylation-mediated silencing of DLEC1 plays an important role in multiple lymphomagenesis, and may serve as a non-invasive tumor marker for lymphoma diagnosis.

Keywords: DLEC1, CpG, Methylation, Tumor suppressor, Lymphoma

\section{Introduction}

Epigenetic silencing of tumor suppressor genes (TSGs) by promoter $\mathrm{CpG}$ methylation and histone modification has been widely recognized as one of the major causes of tumorigenesis including hematological malignancies $[1,2]$. Aberrant methylation of TSG is frequently

\footnotetext{
* Correspondence: qtao@clo.cuhk.edu.hk

${ }^{\dagger}$ Equal contributors

'Shenzhen Institutes of Advanced Technology (SIAT), Chinese Academy of Sciences (CAS)-CUHK, Shenzhen, China

${ }^{2}$ Cancer Epigenetics Laboratory, Department of Clinical Oncology, State Key Laboratory of Oncology in South China, Sir YK Pao Center for Cancer, The Chinese University of Hong Kong and CUHK Shenzhen Research Institute, Shatin, Hong Kong

Full list of author information is available at the end of the article
}

detected even in the early stage of tumorigenesis, suggesting its potential as tumor biomarker for early detection and therapeutic targeting.

Deletions of the 3p22-21.3 region have been identified as one of the earliest molecular events in various malignancies [3], including naspharyngeal [4], head and neck [5], lung [6], gastric [7], breast [8], cervix [9] and renal [10] carcinomas, as well as lymphomas [11]. A growing number of TSGs, including RASSF1A [12,13], BLU/ ZMYND10 [14,15], and CACNA2D2 [16], have been identified in this region $[17,18]$. Frequent inactivation of several 3p21.3 genes as functional TSGs, such as RASSF1 and BLU [14,19], by promoter CpG methylation had been identified associated with tumor initiation and 
progression. For example, promoter methylation of RASSF1A has been shown related to poor prognosis and advanced tumor stage of certain tumor types [20-33]. Restoration of RASSF1A in cancer cell lines inhibited tumor cell growth and metastasis [34]. Thus, 3p22-21.3 is a critical TSG cluster in tumorigenesis [3,18].

Deleted in lung and esophageal cancer 1 (DLEC1), a 3 p22 cluster genes, was first identified as a TSG in esophageal and lung cancers [35]. Downregulation of DLEC1 by promoter methylation has been found in multiple cancers, including nasopharyngeal [36,37], ovarian [38], lung [39], hepatocellular [40], gastric [41], renal [42], and breast carcinomas [43], suggesting its potential as a broad TSG $[44,45]$. Remarkably, DLEC1 was methylated in breast cancer as well as pre-invasive lesions but rarely in normal breast tissues, indicating its potential as an epigenetic marker for early tumors [43].

In this study, we examined the expression and methylation status of DLEC1 in lymphoma cell lines and tissues, and evaluated its potential as a tumor marker for the early detection of hematologic tumors.

\section{Methods}

\section{Cell lines and tumor samples}

Non-Hodgkin and Hodgkin lymphoma cell lines studied included diffuse large B-cell lymphoma (DLBCL) cell lines (OCI-Ly1, Ly3, Ly7, Ly8, Ly18, SUDHL6); peripheral T cell lymphoma (PTCL) cell lines (Ly13.2, Ly17); Burkitt lymphoma (BL) cell lines (AG876, BJAB, Namalwa, Rael, Raji); Hodgkin lymphoma (HL) cell lines (L428, L540, L591, L1236, KM-H2, HD-LM-2, HD-MY-Z) (DSMZ cell collection, Braunschweig, Germany); and natural killer (NK)/T-cell lines (NL) (KHYG-1, SNK6, YT) [46-48]. Cell lines were maintained in RPMI1640 or
Dulbecco's Modified Eagle's Medium supplemented with $10 \%$ fetal calf serum (FBS) (Invitrogen, Paisley, Scotland) and $1 \%$ streptomycin/penicillin at $37^{\circ} \mathrm{C}$ in $5 \% \mathrm{CO}_{2} . \mathrm{HL}$ cell lines were treated with $5 \mu \mathrm{M}$ of 5 -aza- $2^{\prime}$-deoxycytidine (Aza) (Sigma) for 3 days, or further treated with $100 \mathrm{nmol} / \mathrm{L}$ trichostatin A (Cayman Chemical Co., Ann Arbor, MI, USA) for additional $\sim 16 \mathrm{~h}$ as described previously [15,49], and L428 and KM-H2 cell lines were treated with Aza for 6 days.

Normal peripheral blood mononuclear cells (PBMC), lymph node samples, different types of lymphoma samples, as well as sera from healthy individuals and HL patients were collected as previously described, and the reliability and quality of all the studied samples in this study have been confirmed before $[41,47,50]$. The study was approved by Johns Hopkins Medicine Institutional Review Board. Normal adult tissue RNA samples were purchased commercially (Stratagene, La Jolla, CA, USA or Millipore-Chemicon, Billerica, MA, USA). DNA and RNA were extracted from lymphoma cell lines and primary lymphomas using TRIzol reagent (Invitrogen) as previously described [51,52].

\section{Semi-quantitative reverse transcription (RT)-PCR}

RT-PCR was performed as previously described $[40,41]$. Primers used for RT-PCR are: DLEC1A: $5^{\prime}$-ttcctcctcg cctactc, DLEC1B: 5'-aaactcatccagccgctg; GAPDH33: 5'-ga tgaccttgccacagcct, GAPDH55: $5^{\prime}$-atctctgcccctctgctga. RT-PCR was done with 32 cycles for DLEC1 and 23 cycles for GAPDH.

Bisulfite treatment and promoter methylation analysis Bisulfite modification of DNA, methylation-specific PCR (MSP) and bisulfite genomic sequencing (BGS) were
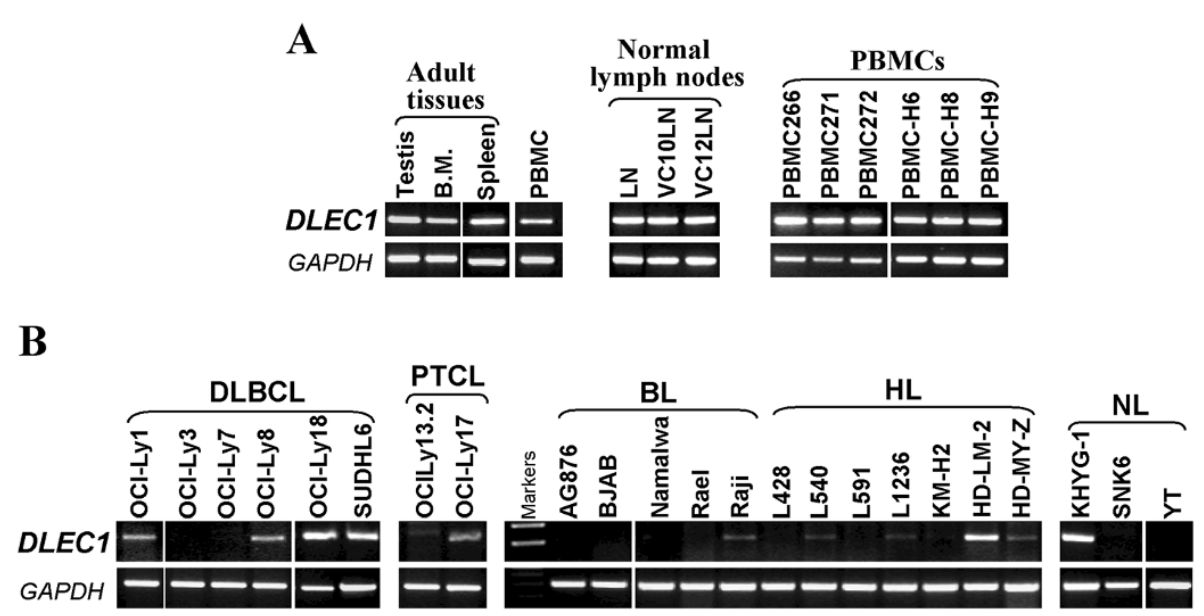

Figure 1 DLEC1 is downregulated in lymphoma cell lines. A. Expression analysis of DLEC1 in normal adult tissues, lymph nodes, and PBMC samples. B. Representative analyses of DLEC1 expression by RT-PCR in lymphoma cell lines. GAPDH was used as internal control. B.M: bone marrow; DLBCL: diffuse large B-cell lymphoma; PTCL: peripheral T cell lymphoma; BL: Burkitt lymphoma; HL: Hodgkin lymphoma; NL: nasal NK/T-cell lymphoma. 
performed as described [53,54]. MSP primers for DLEC1 were: DLEC1m1: 5 '-gtttcgtagttcggtttcgtc; DLEC1m2: 5'-cgaaatatcttaaatacgcaacg; DLEC1u1: 5'-tagttttgtagtttggt tttgtt; DLEC1u2: 5'-acaaaatatcttaaatacacaaca. For BGS, bisulfite-treated DNA was amplified using primers DLEC1BGS1: 5'-gaagatataaatgtttataatgatt; DLEC1BGS4: 5'-aactacaacccaaatcctaa. ANKRD30Am1: $5^{\prime}$-cggtagttgtta tttgtacgc; ANKRD30Am2: 5 -tcctctctcaataaaatcgcg. MSP and BGS were performed for 40 cycles by using the AmpliTaq-Gold DNA polymerase (Applied Biosystems). All primer sets were previously tested for not amplifying any unbisulfited DNA. Amplified BGS products were

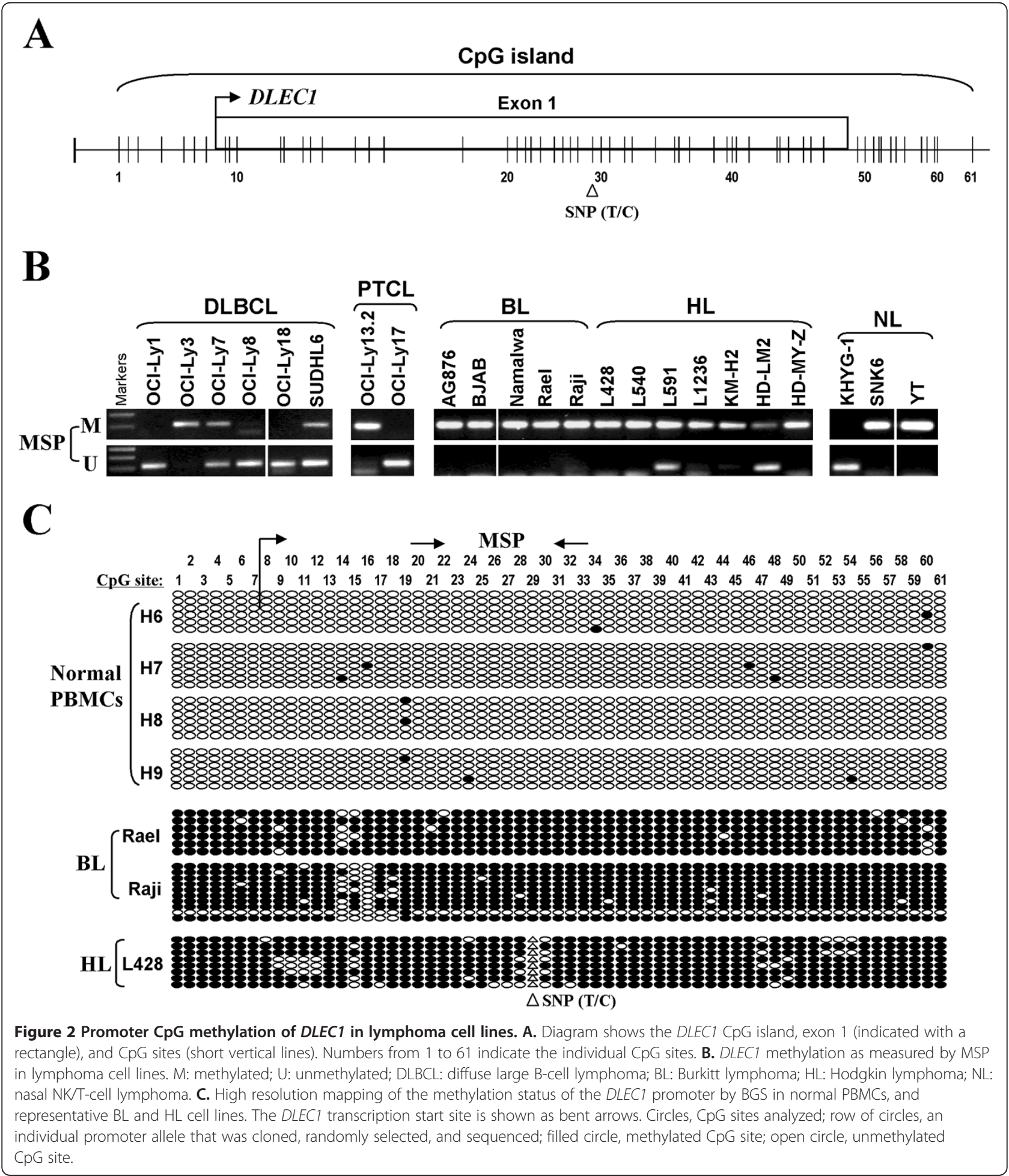


cloned and 5 to 10 colonies were randomly chosen for sequencing.

\section{Results}

DLEC1 was downregulated by promoter CpG methylation in lymphoma cell lines

We first examined the expression of DLEC1 mRNA in 25 non-Hodgkin and Hodgkin lymphoma cell lines by RT-PCR. DLEC1 was highly expressed in the normal lymph node, PBMC samples, as well as human adult testis and bone marrow tissues (Figure $1 \mathrm{~A}$ ), but silenced or reduced in 33\% (2/6) DLBCL, 50\% (1/2) PTCL, 100\% (5/5) BL, 86\% (6/7) HL, and 67\% (2/3) NL cell lines (Figure $1 \mathrm{~B}$ ), indicating that DLEC1 is a candidate TSG for lymphomas.

The promoter and exon 1 region of DLEC1 is a typical CpG island, with a T/C SNP site at CpG\#29 (Figure 2A). MSP analysis showed that DLEC1 promoter methylation was frequently detected in 3/6 DLBCL, 1/2 PTCL, 5/5 $\mathrm{BL}, 7 / 7$ (one weak) HL, and 2/3 NL cell lines (Figure 2B; Table 1), well correlated with its silencing or reduction. DLEC1 methylation was further verified in detail by BGS analysis of $61 \mathrm{CpG}$ sites within the $\mathrm{CpG}$ island. $\mathrm{CpG}$ sites of DLEC1 examined were heavily methylated in $\mathrm{BL}$ cell lines Rael, Raji, and in the HL cell line L428, but rarely in all normal PBMC samples, which confirmed the MSP data (Figure 2C). These results indicate that $D L E C 1$ silencing by promoter methylation is a critical event in lymphomagenesis.

\section{Silencing of DLEC1 could be reversed by pharmacologic demethylation}

To further confirm whether promoter methylation mediates the loss of DLEC1 expression in lymphoma, lymphoma cell lines with methylated and reduced DLEC1 were treated with the DNA methylation inhibitor, Aza, alone or combined with the HDAC inhibitor trichostatin A (TSA). After Aza treatment, DLEC1 expression was significantly induced in cell lines Rael, L428, L1236 and KM-H2. MSP analysis showed increased unmethylated alleles. Similar results were obtained using a combination treatment of Aza and TSA (Figure 3). Demethylation of the DLEC1 promoter was further confirmed by BGS. These results confirmed that promoter $\mathrm{CpG}$ methylation directly mediates $D L E C 1$ silencing in lymphomas.

\section{$D L E C 1$ is frequently methylated in primary lymphomas}

We next investigated DLEC1 methylation in different types of primary lymphomas. Of 58 lymphoma tissues, DLEC1 methylation was detected in 5/6 (83\%) BL, 16/30 (53\%, one weak) HL, 1/10 (10\%) DLBCL, 6/8 (75\%) NL, and $4 / 4$ (100\%, two weak) follicular lymphoma (FL) tumor samples, while no methylation was detected in normal lymph node samples (Figure 4A and B; Table 1).
Table 1 Frequencies of DLEC1 methylation in various lymphoma tissues

\begin{tabular}{lll}
\hline \multirow{2}{*}{ Cell lines } & Lymphoma & $\begin{array}{l}\text { DLEC1 promoter } \\
\text { (methylated) }\end{array}$ \\
\cline { 2 - 3 } & Diffuse large B-cell lymphoma & $50 \%(3 / 6)$ \\
\cline { 2 - 3 } & Peripheral T-cell lymphoma & $50 \%(1 / 2)$ \\
\cline { 2 - 3 } & Burkitt lymphoma & $100 \%(5 / 5)$ \\
\cline { 2 - 3 } & Hodgkin lymphoma & $100 \%(7 / 7$, one weak) \\
\cline { 2 - 3 } Numors & Bural NKTT-cell lymphoma & $67 \%(2 / 3)$ \\
\cline { 2 - 3 } & Diffuse large B-cell lymphoma & $10 \%(1 / 10)$ \\
\cline { 2 - 3 } & Nasal NKJT-cell lymphoma & $75 \%(6 / 8)$ \\
\cline { 2 - 3 } & Hodgkin lymphoma & $53 \%(16 / 30$, one weak) \\
\cline { 2 - 3 } & Follicular lymphoma & $100 \%(4 / 4$, two weak) \\
\hline Normal samples & Normal lymph node & $23 \%(3 / 13)$ \\
\cline { 2 - 3 } & Normal sera & $0 / 20$ \\
\hline
\end{tabular}

Unmethylated bands were detected in all samples due to the inevitable inclusion of non-tumor cells in the analysis. Furthermore, the reduction or silencing of DLEC1 expression was observed in 6 out of 7 (86\%) NL tumors as measured by RT-PCR.

Furthermore as a pilot study, we examined DLEC1 methylation in serum samples of $13 \mathrm{HL}$ patients with sera from 20 healthy individuals as controls. ANKRD30A is a normally methylated gene, thus used as an internal control for validating genomic DNA integrity of these samples, in addition to unmethylated DLEC1. Results showed that DLEC1 methylation was detected in 3/13 (23\%) sera from HL patients (Figure 4D) but not in any normal sera.

\section{Discussion}

$D L E C 1$ is located in the commonly deleted region $3 \mathrm{p} 22$ 21.3 [3,18]. A cluster of TSGs, including RASSF1A, BLU, and $C A C N A 2 D 2$, has been identified within this region. Silencing of RASSF1A, BLU, as well as DLEC1 by promoter CpG methylation had been extensively identified in multiple human cancers. Notably, promoter methylation of several 3p22-21.3 TSGs, such as RASSF1A and BLU, has also been identified in lymphomas [50,55], suggesting that TSGs in this region are frequently susceptible to epigenetic disruption during lymphoma pathogenesis.

Here, we report that DLEC1 is frequently silenced by promoter methylation both in lymphoma cell lines and primary lymphomas, but seldom in normal lymph nodes and PBMCs. Pharmacologic demethylation could reactivate $D L E C 1$ expression, suggesting that epigenetic mechanism including DNA methylation and histone modification mediates DLEC1 transcriptional silencing. As primary tumor tissues usually contain infiltrating 

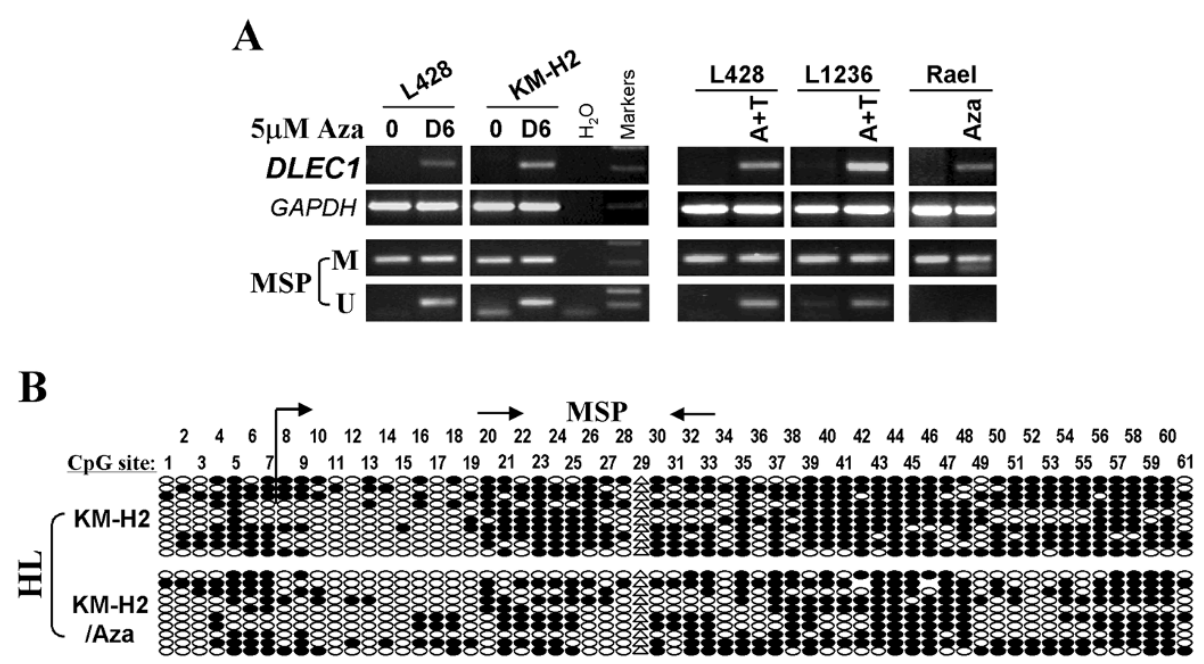

$\triangle \mathrm{SNP}(\mathrm{T} / \mathrm{C})$

Figure 3 Pharmacologic demethylation restored DLEC1 expression in methylated/silenced lymphoma cell lines. A. Expression and methylation analyses of DLEC1 in HL cell lines with Aza treatment or combined with TSA (A+T). M: methylated; U: unmethylated. B. BGS analysis of DLEC1 methylation in lymphoma cell line KM-H2 before and after $5 \mu \mathrm{M}$ Aza treatment.

non-malignant cells such as lymphocytes, unmethylated alleles were detected in all the tumor samples which also acting as an internal control for genomic DNA integrity. DLEC1 unmethylated alleles and ANKRD30A methylated alleles detected in different types of normal and lymphoma samples indicated the reliability of these samples as shown before. DLEC1 methylation showed a relatively low frequency in DLBCL samples, compared to other lymphoma types. The reason for this difference is not clear probably due to the special biologic features of
A

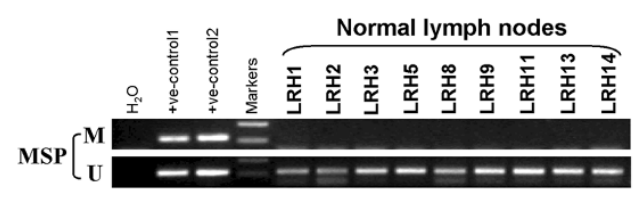

C

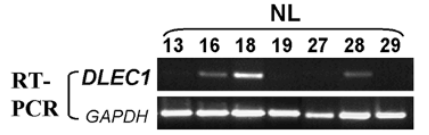

B

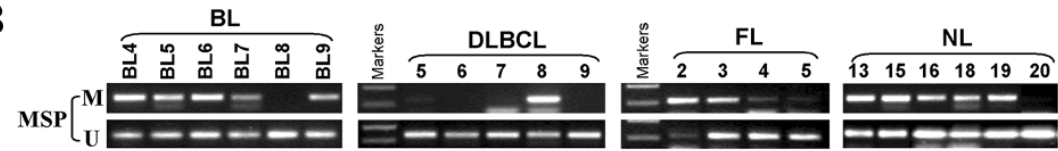

HL

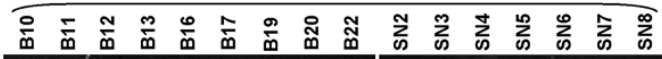

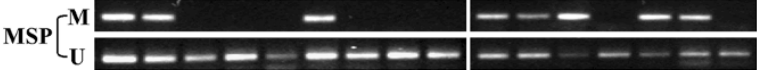
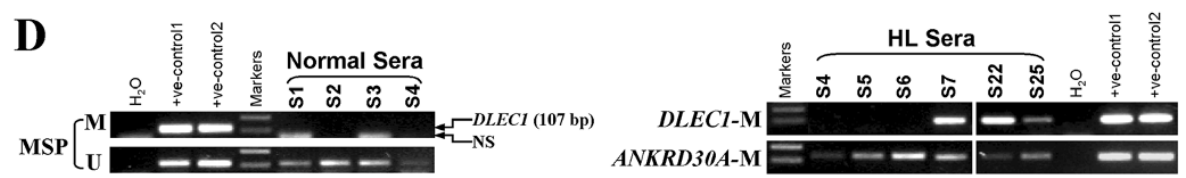

Figure 4 DLEC1 is frequently methylated in lymphoma tissues. A. MSP analysis of DLEC1 methylation in normal lymph node samples. Templates used for positive controls are: bisulfite treated DNA from HCT116 (+ve-control1) and HT-29 (+ve-control2) cell lines for methylation; SW480 (+ve-control1) and SNU16 (+ve-control2) cell lines for unmethylation. B. Representative analyses of DLEC1 methylation in primary lymphomas by MSP in primary lymphoma BL, DLBCL, HL and FL samples. BL: Burkitt lymphoma; DLBCL: diffuse large B-cell lymphoma; HL: Hodgkin lymphoma; NL: nasal NK/T-cell lymphoma; FL: follicular lymphoma. C. Representative analysis of DLEC1 expression in NL tumors. GAPDH was used as an internal control. D. Representative MSP analysis of DLEC1 methylation in serum samples from HL patients and normal controls. Positive controls: bisulfite treated DNA from HCT116 (+ve-control1) and HT-29 (+ve-control2) cell lines. M: methylated; NS: non-specific band. 
DLBCL, which needs to be further confirmed by large sample size. Our results suggest that epigenetic silencing of DLEC1 is important for lymphoma pathogenesis. Remarkably, $D L E C 1$ is specifically methylated in sera of $\mathrm{HL}$ patients, suggesting its potential as an epigenetic biomarker for the non-invasive diagnosis of lymphomas.

\section{Conclusions}

This study identifies the frequent epigenetic inactivation of DLEC1 in various lymphomas and demonstrates its potential as a non-invasive tumor marker for the detection of lymphomas. More molecular studies on the tumor suppressive functions of DLEC1 in lymphoma pathogenesis are needed.

\section{Competing interests}

The authors declare no conflict of interest.

\section{Authors' contributions}

$Z W$ and $L L$ analyzed data and drafted the manuscript. XS and ZW acquired data. ZG, GS, PGM and AR provided material and reviewed the manuscript. PGM contributed to the writing of the manuscript. QT conceived and supervised the study, analyzed data and finalized the manuscript. All authors read and approved the final manuscript.

\section{Acknowledgments}

This study was supported by National Natural Science Foundation of China (\# 81071634 and 81172582), Shenzhen Science Fund for Distinguished Young Scholars (\#JC201005270328A) the Leukaemia Lymphoma Research of the United Kingdom and the grants from The Chinese University of Hong Kong. We thank Dr. Riccardo Dalla-Favera for the DLBCL cell lines, Drs. Teresa Marafioti and (David Y Mason) for the L1236 cell line, Drs. Norio Shimizu for the SNK-6 lymphoma cell line.

\section{Author details \\ 'Shenzhen Institutes of Advanced Technology (SIAT), Chinese Academy of Sciences (CAS)-CUHK, Shenzhen, China. ${ }^{2}$ Cancer Epigenetics Laboratory, Department of Clinical Oncology, State Key Laboratory of Oncology in South China, Sir YK Pao Center for Cancer, The Chinese University of Hong Kong and CUHK Shenzhen Research Institute, Shatin, Hong Kong. ${ }^{3}$ Department of Pathology, Peking University Health Science Center, Beijing, China. ${ }^{4}$ Department of Pathology, University of Hong Kong, Shatin, Hong Kong. ${ }^{5}$ Cancer Research UK Institute for Cancer Studies, University of Birmingham, Birmingham, UK. ${ }^{6}$ Johns Hopkins Singapore and Sidney Kimmel Comprehensive Cancer Center, Johns Hopkins School of Medicine, Baltimore, $M D$, USA.}

Received: 22 July 2012 Accepted: 4 October 2012

Published: 11 October 2012

\section{References}

1. Jones PA, Baylin SB: The epigenomics of cancer. Cell 2007, 128:683-692.

2. Baylin SB, Ohm JE: Epigenetic gene silencing in cancer - a mechanism for early oncogenic pathway addiction? Nat Rev Cancer 2006, 6:107-116.

3. Hesson LB, Cooper WN, Latif F: Evaluation of the 3p21.3 tumoursuppressor gene cluster. Oncogene 2007, 26:7283-7301.

4. Cheng Y, Poulos NE, Lung ML, Hampton G, Ou B, Lerman MI, Stanbridge EJ: Functional evidence for a nasopharyngeal carcinoma tumor suppressor gene that maps at chromosome 3p21.3. Proc Natl Acad Sci USA 1998, 95:3042-3047.

5. Maestro R, Gasparotto D, Vukosavljevic T, Barzan L, Sulfaro S, Boiocchi M: Three discrete regions of deletion at $3 p$ in head and neck cancers. Cancer Res 1993, 53:5775-5779.

6. Hibi K, Takahashi T, Yamakawa K, Ueda R, Sekido Y, Ariyoshi Y, Suyama M, Takagi H, Nakamura Y: Three distinct regions involved in $3 p$ deletion in human lung cancer. Oncogene 1992, 7:445-449.
7. Pizzi S, Azzoni C, Bassi D, Bottarelli L, Milione M, Bordi C: Genetic alterations in poorly differentiated endocrine carcinomas of the gastrointestinal tract. Cancer 2003, 98:1273-1282.

8. Yang Q, Yoshimura G, Mori I, Sakurai T, Kakudo K: Chromosome 3p and breast cancer. J Hum Genet 2002, 47:453-459.

9. Acevedo CM, Henriquez M, Emmert-Buck MR, Chuaqui RF: Loss of heterozygosity on chromosome arms $3 p$ and $6 q$ in microdissected adenocarcinomas of the uterine cervix and adenocarcinoma in situ. Cancer 2002, 94:793-802.

10. van den Berg A, Buys $\mathrm{CH}$ : Involvement of multiple loci on chromosome 3 in renal cell cancer development. Genes Chromosomes Cancer 1997, 19:59-76.

11. Kimm LR, DeLeeuw RJ, Savage KJ, Rosenwald A, Campo E, Delabie J, Ott G Muller-Hermelink H-K, Jaffe ES, Rimsza LM, et al: Frequent occurrence of deletions in primary mediastinal B-cell lymphoma. Genes Chromosomes Cancer 2007, 46:1090-1097

12. Agathanggelou A, Cooper WN, Latif F: Role of the Ras-association domain family 1 tumor suppressor gene in human cancers. Cancer Res 2005, 65:3497-3508.

13. Dammann R, Schagdarsurengin U, Seidel C, Strunnikova M, Rastetter M, Baier K, Pfeifer GP: The tumor suppressor RASSF1A in human carcinogenesis: an update. Histol Histopathol 2005, 20:645-663.

14. Agathanggelou A, Dallol A, Zochbauer-Muller S, Morrissey C, Honorio S, Hesson L, Martinsson T, Fong KM, Kuo MJ, Yuen PW, et al: Epigenetic inactivation of the candidate 3p21.3 suppressor gene BLU in human cancers. Oncogene 2003, 22:1580-1588.

15. Qiu GH, Tan LK, Loh KS, Lim CY, Srivastava G, Tsai ST, Tsao SW, Tao Q: The candidate tumor suppressor gene BLU, located at the commonly deleted region 3p21.3, is an E2F-regulated, stress-responsive gene and inactivated by both epigenetic and genetic mechanisms in nasopharyngeal carcinoma. Oncogene 2004, 23:4793-4806.

16. Lerman MI, Minna JD: identification and evaluation of the resident candidate tumor suppressor genes. the international lung cancer chromosome 3p21.3 tumor suppressor gene consortium. Cancer Res 2000, 60:6116-6133.

17. Ji L, Nishizaki M, Gao B, Burbee D, Kondo M, Kamibayashi C, Xu K, Yen N, Atkinson EN, Fang $B$, et al: Expression of several genes in the human chromosome 3 p21.3 homozygous deletion region by an adenovirus vector results in tumor suppressor activities in vitro and in vivo. Cancer Res 2002, 62:2715-2720.

18. Ji L, Minna JD, Roth JA: $3 p 21.3$ tumor suppressor cluster: prospects for translational applications. Future Oncol 2005, 1:79-92.

19. Hesson L, Bieche I, Krex D, Criniere E, Hoang-Xuan K, Maher ER, Latif F: Frequent epigenetic inactivation of RASSF1A and BLU genes located within the critical 3p21.3 region in gliomas. Oncogene 2004, 23:2408-2419.

20. Wang $Y, Y u Z$, Wang $T$, Zhang J, Hong $L$, Chen L: Identification of epigenetic aberrant promoter methylation of RASSF1A in serum DNA and its clinicopathological significance in lung cancer. Lung Cancer 2007 56:289-294.

21. Lai HC, Lin YW, Chang CC, Wang HC, Chu TW, Yu MH, Chu TY: Hypermethylation of two consecutive tumor suppressor genes, BLU and RASSF1A, located at 3p21.3 in cervical neoplasias. Gynecol Oncol 2007, 104:629-635.

22. Pan ZG, Kashuba VI, Liu XQ, Shao JY, Zhang RH, Jiang JH, Guo C, Zabarovsky E, Ernberg I, Zeng YX: High frequency somatic mutations in RASSF1A in nasopharyngeal carcinoma. Cancer Biol Ther 2005, 4:1116-1122.

23. Pizzi S, Azzoni C, Bottarelli L, Campanini N, D'Adda T, Pasquali C, Rossi G, Rindi G, Bordi C: RASSF1A promoter methylation and 3p21.3 loss of heterozygosity are features of foregut, but not midgut and hindgut, malignant endocrine tumours. J Pathol 2005, 206:409-416.

24. Tomizawa Y, lijima H, Nomoto T, Iwasaki Y, Otani Y, Tsuchiya S, Saito R, Dobashi K, Nakajima T, Mori M: Clinicopathological significance of aberrant methylation of RARbeta2 at 3p24, RASSF1A at 3p21.3, and FHIT at 3p14.2 in patients with non-small cell lung cancer. Lung Cancer 2004, 46:305-312.

25. Chow LS, Lo KW, Kwong J, To KF, Tsang KS, Lam CW, Dammann R, Huang DP: RASSF1A is a target tumor suppressor from $3 p 21.3$ in nasopharyngeal carcinoma. Int J Cancer 2004, 109:839-847.

26. Horiguchi K, Tomizawa Y, Tosaka M, Ishiuchi S, Kurihara H, Mori M, Saito N: Epigenetic inactivation of RASSF1A candidate tumor suppressor gene at 3p21.3 in brain tumors. Oncogene 2003, 22:7862-7865. 
27. Cohen $Y$, Singer G, Lavie O, Dong SM, Beller U, Sidransky D: The RASSF1A tumor suppressor gene is commonly inactivated in adenocarcinoma of the uterine cervix. Clin Cancer Res 2003, 9:2981-2984

28. Wagner KJ, Cooper WN, Grundy RG, Caldwell G, Jones C, Wadey RB, Morton D, Schofield PN, Reik W, Latif F, Maher ER: Frequent RASSF1A tumour suppressor gene promoter methylation in Wilms' tumour and colorectal cancer. Oncogene 2002, 21:7277-7282

29. Liu L, Yoon JH, Dammann R, Pfeifer GP: Frequent hypermethylation of the RASSF1A gene in prostate cancer. Oncogene 2002, 21:6835-6840.

30. Hogg RP, Honorio S, Martinez A, Agathanggelou A, Dallol A, Fullwood P, Weichselbaum R, Kuo MJ, Maher ER, Latif F: Frequent 3p allele loss and epigenetic inactivation of the RASSF1A tumour suppressor gene from region 3p21.3 in head and neck squamous cell carcinoma. Eur J Cancer 2002, 38:1585-1592.

31. Dreijerink K, Braga E, Kuzmin I, Geil L, Duh FM, Angeloni D, Zbar B, Lerman MI, Stanbridge EJ, Minna JD, et al: The candidate tumor suppressor gene, RASSF1A, from human chromosome 3 p21.3 is involved in kidney tumorigenesis. Proc Natl Acad Sci USA 2001, 98:7504-7509.

32. Lo KW, Kwong J, Hui AB, Chan SY, To KF, Chan AS, Chow LS, Teo PM, Johnson PJ, Huang DP: High frequency of promoter hypermethylation of RASSF1A in nasopharyngeal carcinoma. Cancer Res 2001, 61:3877-3881.

33. Burbee DG, Forgacs E, Zochbauer-Muller S, Shivakumar L, Fong K, Gao B, Randle $D$, Kondo M, Virmani A, Bader S, et al: Epigenetic inactivation of RASSF1A in lung and breast cancers and malignant phenotype suppression. J Natl Cancer Inst 2001, 93:691-699.

34. Chow LS, Lam CW, Chan SY, Tsao SW, To KF, Tong SF, Hung WK, Dammann $R$, Huang DP, Lo KW: Identification of RASSF1A modulated genes in nasopharyngeal carcinoma. Oncogene 2006, 25:310-316.

35. Daigo Y, Nishiwaki T, Kawasoe T, Tamari M, Tsuchiya E, Nakamura Y: Molecular cloning of a candidate tumor suppressor gene, DLC1, from chromosome 3p21.3. Cancer Res 1999, 59:1966-1972.

36. Kwong J, Chow LS, Wong AY, Hung WK, Chung GT, To KF, Chan FL, Daigo $Y$, Nakamura Y, Huang DP, Lo KW: Epigenetic inactivation of the deleted in lung and esophageal cancer 1 gene in nasopharyngeal carcinoma. Genes Chromosomes Cancer 2007, 46:171-180.

37. Ayadi W, Karray-Hakim H, Khabir A, Feki L, Charfi S, Boudawara T, Ghorbel A, Daoud J, Frikha M, Busson P, Hammami A: Aberrant methylation of p16, DLEC1, BLU and E-cadherin gene promoters in nasopharyngeal carcinoma biopsies from Tunisian patients. Anticancer Res 2008, 28:2161-2167.

38. Kwong J, Lee JY, Wong KK, Zhou X, Wong DT, Lo KW, Welch WR, Berkowitz RS, Mok SC: Candidate tumor-suppressor gene DLEC1 is frequently downregulated by promoter hypermethylation and histone hypoacetylation in human epithelial ovarian cancer. Neoplasia 2006 8:268-278

39. Seng TJ, Currey N, Cooper WA, Lee CS, Chan C, Horvath L, Sutherland RL, Kennedy C, McCaughan B, Kohonen-Corish MR: DLEC1 and MLH1 promoter methylation are associated with poor prognosis in non-small cell lung carcinoma. Br J Cancer 2008, 99:375-382.

40. Qiu GH, Salto-Tellez M, Ross JA, Yeo W, Cui Y, Wheelhouse N, Chen GG, Harrison D, Lai P, Tao Q, Hooi SC: The tumor suppressor gene DLEC1 is frequently silenced by DNA methylation in hepatocellular carcinoma and induces G1 arrest in cell cycle. J Hepatol 2008, 48:433-441.

41. Ying J, Poon FF, Yu J, Geng H, Wong AH, Qiu GH, Goh HK, Rha SY, Tian L, Chan AT, et al: DLEC1 is a functional 3p22.3 tumour suppressor silenced by promoter $\mathrm{CpG}$ methylation in colon and gastric cancers. $\mathrm{Br} \mathrm{J}$ Cancer 2009, 100:663-669.

42. Zhang Q, Ying J, Li J, Fan Y, Poon FF, Ng KM, Tao Q, Jin J: Aberrant promoter methylation of DLEC1, a critical 3p22 tumor suppressor for renal cell carcinoma, is associated with more advanced tumor stage. J Urol 2010, 184:731-737.

43. Park SY, Kwon HJ, Lee HE, Ryu HS, Kim SW, Kim JH, Kim IA, Jung N, Cho NY, Kang GH: Promoter CpG island hypermethylation during breast cancer progression. Virchows Arch 2010, 458:73-84

44. Kang GH, Lee S, Cho NY, Gandamihardja T, Long TI, Weisenberger DJ, Campan M, Laird PW: DNA methylation profiles of gastric carcinoma characterized by quantitative DNA methylation analysis. Lab Invest 2008, 88:161-170

45. Zhang Y, Wang R, Song H, Huang G, Yi J, Zheng Y, Wang J, Chen L: Methylation of multiple genes as a candidate biomarker in non-small cell lung cancer. Cancer Lett 2011, 303:21-28.
46. Ying J, Li H, Murray P, Gao Z, Chen YW, Wang Y, Lee KY, Chan AT, Ambinder RF, Srivastava G, Tao Q: Tumor-specific methylation of the 8 p22 tumor suppressor gene DLC1 is an epigenetic biomarker for Hodgkin, nasal NK/T-cell and other types of lymphomas. Epigenetics 2007, 2:15-21.

47. Murray PG, Fan Y, Davies G, Ying J, Geng H, Ng KM, Li H, Gao Z, Wei W, Bose $S$, et al: Epigenetic silencing of a proapoptotic cell adhesion molecule, the immunoglobulin superfamily member IGSF4, by promoter CpG methylation protects Hodgkin lymphoma cells from apoptosis. Am J Pathol 2010, 177:1480-1490.

48. Ying J, Li H, Chen YW, Srivastava G, Gao Z, Tao Q: WNT5A is epigenetically silenced in hematologic malignancies and inhibits leukemia cell growth as a tumor suppressor. Blood 2007, 110:4130-4132.

49. Ying J, Li H, Seng TJ, Langford C, Srivastava G, Tsao SW, Putti T, Murray P, Chan AT, Tao Q: Functional epigenetics identifies a protocadherin PCDH10 as a candidate tumor suppressor for nasopharyngeal, esophageal and multiple other carcinomas with frequent methylation. Oncogene 2006, 25:1070-1080.

50. Murray PG, Qiu GH, Fu L, Waites ER, Srivastava G, Heys D, Agathanggelou A, Latif F, Grundy RG, Mann JR, et al: Frequent epigenetic inactivation of the RASSF1A tumor suppressor gene in Hodgkin's lymphoma. Oncogene 2004, 23:1326-1331.

51. Cheng $Y$, Geng $H$, Cheng SH, Liang P, Bai Y, Li J, Srivastava G, Ng MH, Fukagawa $T, W u$, et al: KRAB zinc finger protein ZNF382 is a proapoptotic tumor suppressor that represses multiple oncogenes and is commonly silenced in multiple carcinomas. Cancer Res 2010, 70:6516-6526.

52. Jin $H$, Wang $X$, Ying J, Wong AH, Cui $Y$, Srivastava G, Shen ZY, Li EM, Zhang $Q$, Jin J, et al: Epigenetic silencing of a $\mathrm{Ca}(2+)$-regulated Ras GTPase-activating protein RASAL defines a new mechanism of Ras activation in human cancers. Proc Natl Acad Sci USA 2007, 104:12353-12358

53. Tao Q, Robertson KD, Manns A, Hildesheim A, Ambinder RF: The Epstein-Barr virus major latent promoter $Q p$ is constitutively active, hypomethylated, and methylation sensitive. J Virol 1998, 72:7075-7083.

54. Tao Q, Swinnen L, Yang J, Srivastava G, Robertson KD, Ambinder RF: Methylation status of the Epstein-Barr virus major latent promoter $C$ in iatrogenic B cell lymphoproliferative disease. Application of PCR-based analysis. Am J Pathol 1999, 155:619-625.

55. Toujani S, Dessen $P$, Ithzar N, Danglot G, Richon C, Vassetzky Y, Robert T, Lazar V, Bosq J, Da Costa L, et al: High resolution genome-wide analysis of chromosomal alterations in Burkitt's lymphoma. PLoS One 2009, 4:e7089.

\section{doi:10.1186/1479-5876-10-209}

Cite this article as: Wang et al:: Epigenetic silencing of the 3p22 tumor suppressor DLEC1 by promoter CpG methylation in non-Hodgkin and Hodgkin lymphomas. Journal of Translational Medicine 2012 10:209.

\section{Submit your next manuscript to BioMed Central and take full advantage of:}

- Convenient online submission

- Thorough peer review

- No space constraints or color figure charges

- Immediate publication on acceptance

- Inclusion in PubMed, CAS, Scopus and Google Scholar

- Research which is freely available for redistribution 